\title{
KONCEPCJA ZABUDOWY ABSORPCYJNEJ POMPY CIEPŁA W UKLADZIE BLOKU PAROWEGO
}

\begin{abstract}
W pracy przedstawiono koncepcję zabudowy absorpcyjnej pompy ciepła w układzie nadkrytycznego bloku parowego, mającej na celu jego uciepłownienie. Zaproponowana koncepcja została poddana analizie symulacyjnej, którą zrealizowano z wykorzystaniem środowiska IPSEpro firmy SimTech. W pracy dokonano integracji absorpcyjnej pompy ciepła $z$ układem bloku parowego, a analiza wykazała duży potencjał tego rozwiązania. Wynika z niej, że zabudowa pompy ciepła pozwala na znaczące oszczędności paliwa oraz wyraźne ograniczenie emisji dwutlenku węgla. Ponadto zastosowanie absorpcyjnej pompy ciepła pozwala ograniczyć negatywny, ze względu na produkcję energii elektrycznej, wpływ uciepłownienia bloku. Przeprowadzone obliczenia symulacyjne pozwoliły na ustalenie i porównanie wskaźników sprawności elektrycznej brutto oraz sprawności w kogeneracji dla układu z wymiennikiem ciepła i absorpcyjną pompą ciepła.
\end{abstract}

Słowa kluczowe: kogeneracja, modelowanie obiegów cieplnych, symulacje numeryczne, absorpcyjne pompy ciepła

\section{Wstęp}

Paliwa kopalne w postaci węgla kamiennego i brunatnego stanowią podstawowe źródło energii w polskiej energetyce zawodowej. W kotłach energetycznych następuje proces ich spalania, w wyniku czego jest uzyskiwana para na potrzeby produkcji energii elektrycznej oraz gorąca woda na cele grzewcze. Realizacja procesu przygotowania ciepła na cele grzewcze odbywa się w ciepłowniach, elektrociepłowniach lub elektrowniach wyposażonych w odpowiednie upusty pary i instalacje wymienników ciepła. Praca ciepłowni wytwarzających jedynie ciepło ma charakter sezonowy i zależy głównie od warunków otoczenia, a ich sprawność waha się w granicach od 60 do 90\%. Jednoczesną produkcję ciepła i energii elektrycznej umożliwiają układy elektrociepłowni, np. z turbinami przeciwprężnymi, których sprawność dochodzi do 85-90\%. W więk-

\footnotetext{
1 Autor do korespondencji/corresponding author: Robert Zarzycki, Politechnika Częstochowska, ul. Brzeźnicka 60a, 42-200 Częstochowa, tel.: (34) 3257334, e-mail: zarzycki@ is.pcz.czest.pl.

${ }^{2}$ Marcin Panowski, Politechnika Częstochowska, e-mail: mpanowski@ is.pcz.czest.pl.
} 
szości przypadków zapotrzebowanie na energię elektryczną oraz ciepło są od siebie niezależne. Układ skojarzonej produkcji obu nośników energii z turbiną przeciwprężną, słuszny ze względów energetycznych, posiada jednak podstawową wadę, którą jest związanie produkcji energii elektrycznej z produkcją ciepła.

W przypadku bloków elektrowni parowych, których moce w polskim systemie energetycznym osiągają poziom $900 \mathrm{MWe}$, a sprawność zbliża się do poziomu 50\% brutto, znacząca część energii w postaci ciepła niskotemperaturowego jest bezpowrotnie tracona do otoczenia. Pomimo rozwoju coraz to doskonalszych procesów konwersji energii chemicznej w elektryczną w elektrowniach parowych, ze względu na ograniczenia natury termodynamicznej nie jest możliwe wyeliminowanie utraty do otoczenia ciepła chłodzenia. Bezpośrednie wykorzystanie tego ciepła do celów grzewczych czy technologicznych jest także niemożliwe ze względu na jego niską temperaturę.

W pracy przedstawiono propozycję wykorzystania ciepła odpadowego na potrzeby zasilania sieci ciepłowniczej z wykorzystaniem absorpcyjnej pompy ciepła. Takie rozwiązanie pozwala na uciepłownienie bloku parowego przy możliwie małym jego negatywnym wpływie na produkcję energii elektrycznej.

\section{Kondensacyjny blok parowy}

W niniejszej pracy rozważono koncepcję zabudowy absorpcyjnej pompy ciepła w układzie nadkrytycznego bloku parowego o mocy 900 MWe, dla którego na etapie projektu nie przewidziano możliwości uciepłownienia. Schemat bloku przedstawiono na rys. 1 .

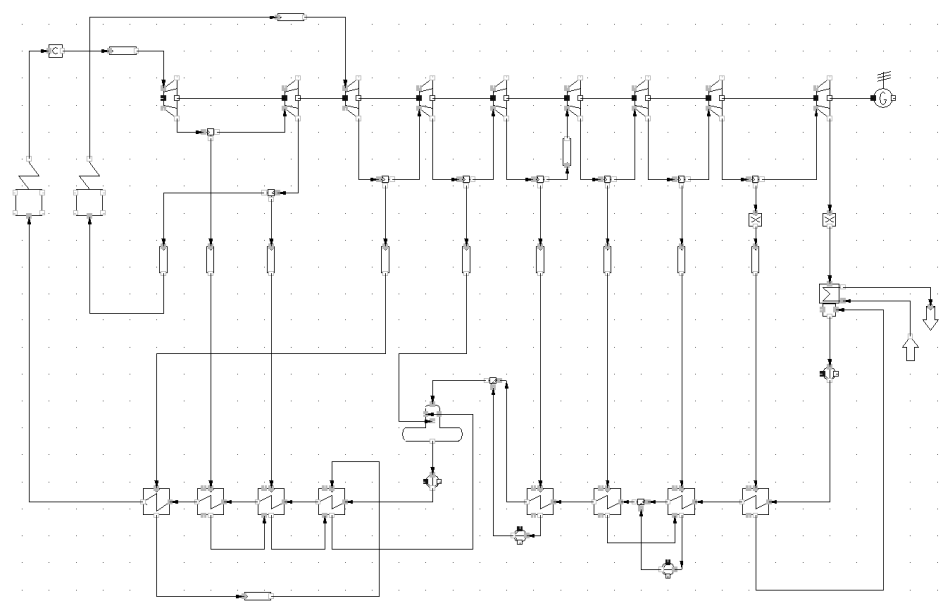

Rys. 1. Schemat nadkrytycznego bloku parowego o mocy $900 \mathrm{MWe}$

Fig. 1. The scheme of $900 \mathrm{MWe}$ supercritical steam power unit 
Podstawowe parametry analizowanego bloku to ciśnienie i temperatura pary świeżej, wynoszące odpowiednio $30 \mathrm{MPa}$ i $650^{\circ} \mathrm{C}$, natomiast w przypadku pary wtórnej odpowiednio $6 \mathrm{MPa}$ i $670^{\circ} \mathrm{C}$. Sprawność brutto bloku wynosi $49,04 \%$. W nominalnych warunkach eksploatacyjnych do otoczenia wyprowadzany jest $\mathrm{z}$ chłodni strumień ciepła $\mathrm{w}$ ilości ok. $850 \mathrm{MW}_{\mathrm{t}}$, a parametry wody chłodzącej na wylocie i wlocie do skraplacza wynoszą odpowiednio 29,5 oraz $18,5^{\circ} \mathrm{C}$. W celu umożliwienia produkcji ciepła na potrzeby grzewcze konieczny jest pobór pary z jednego z upustów turbiny na potrzeby zasilania wymiennika ciepłowniczego. W tym przypadku należy się spodziewać, że nastąpi spadek mocy elektrycznej bloku proporcjonalny do strumienia pary pobieranej na cele ciepłownicze.

\section{Absorpcyjna pompa ciepła}

Urządzenia wymuszające przepływ ciepła z obszaru o niższej temperaturze do obszaru o temperaturze wyższej są nazywane pompami ciepła. Aby możliwy był transport ciepła, konieczne jest dostarczenie energii z zewnątrz do realizacji tego procesu. W technice można spotkać wiele różnych konstrukcji pomp ciepła. Głównymi typami są: pompy sprężarkowe, adsorpcyjne i absorpcyjne. Istotą absorpcyjnych pomp ciepła (APC) jest odzysk ciepła niskotemperaturowego, które wraz z ciepłem wysokotemperaturowym, np. w postaci gorącej wody, pary lub spalin, pozwala wytworzyć ciepło użyteczne, m.in. do celów grzewczych bądź technologicznych. W układzie urządzenia APC czynnikiem roboczym może być roztwór amoniaku i wody lub roztwór wodny bromku litu (LiBr). Schemat takiej pompy ciepła, opartej na wodnym roztworze bromku litu, opracowany w środowisku IPSEpro przedstawiono na rys. 2.

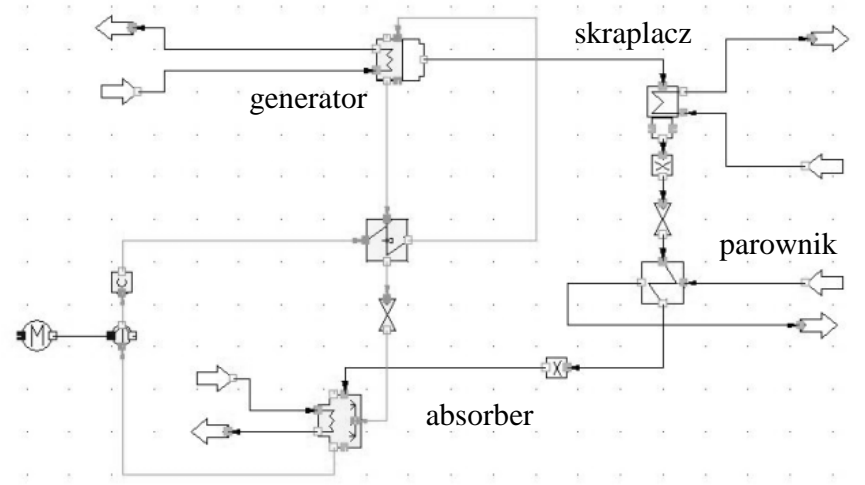

Rys. 2. Model symulacyjny bromowo-litowej absorpcyjnej pompy ciepła

Fig. 2. Simulation model of bromine-lithium absorption heat pump 
W generatorze APC kosztem ciepła dostarczonego w postaci pary (z upustu turbiny) następuje odparowanie pary wodnej z rozcieńczonego roztworu bromku litu i wody. Odparowanie w generatorze jest możliwe dzięki ciśnieniu znacząco niższemu od atmosferycznego. Odparowana czysta para wodna przechodzi do skraplacza i zostaje skondensowana, oddając ciepło przez przeponowy wymiennik. Uzyskana w ten sposób woda stanowiąca czynnik roboczy jest podawana przez układ dławiący do parownika, gdzie odparowując na wymienniku przeponowym w warunkach wysokiej próżni, odbiera ciepło nieużyteczne, niskotemperaturowe z dolnego źródła. Podczas odbioru ciepła woda wrze. Powstała w parowniku para wodna jest następnie pochłaniana $w$ absorberze przez roztwór stężony bromku litu, z którego wcześniej w generatorze odparowała, utrzymując w ten sposób wysoką próżnię w urządzeniu, a więc i niską temperaturę wrzenia w parowniku. Proces absorpcji jest silnie egzotermiczny, dlatego też jest wymagany odbiór znaczącej ilości ciepła przez wymiennik przeponowy, co stanowi dodatkowe źródło energii oraz pierwszy stopień podgrzewu wody wlotowej. Stężony roztwór, pochłaniając parę, rozcieńcza się, a następnie jest przetłaczany przez pompę z powrotem do generatora, gdzie woda z roztworu zostaje odparowana, stężony roztwór zostaje przepompowany do absorbera i cykl się powtarza.

Najnowsze konstrukcje APC charakteryzują się efektywnością cieplną (COP) na poziomie 1.6-2.1, w zależności od parametrów pracy i konstrukcji [1]. Praca pompy ciepła jest także uwarunkowana wieloma charakterystykami, np. mocą grzewczą uzależnioną od ciśnienia pary zasilającej generator (rys. 3.), temperatury wody gorącej zasilającej skraplacz czy temperatury źródła niskotemperaturowego zasilającego parownik. Dysponując parametrami nominalnymi pracy APC oraz charakterystykami względnymi zmienności głównych parametrów (rys. 3.), można opracować wiarygodny model symulacyjny jednostki APC i zintegrować go z modelem symulacyjnym bloku parowego.

\section{Obliczenia bloku parowego zintegrowanego $\mathrm{z}$ absorpcyjną pompą ciepła}

Proces obliczeń termodynamicznych bloku parowego zintegrowanego $\mathrm{z}$ APC zrealizowano $\mathrm{z}$ wykorzystaniem oprogramowania symulacyjnego IPSEpro, które znajduje zastosowanie podczas modelowania różnego typu systemów energetycznych. Wiarygodność wyników uzyskiwanych dzięki zastosowaniu tego narzędzia przy odwzorowywaniu rzeczywistych obiektów energetycznych została wielokrotnie sprawdzona i potwierdzona $[2,3]$. W niniejszej pracy założono, że blok zostanie uciepłowniony mocą 100 MWt. Na potrzeby realizacji tego zadania została dobrana bromowo-litowa pompa ciepła o mocy nominalnej 35 MWt. Przewidziano zabudowę trzech takich jednostek. Pompa ta w warunkach nominalnych pozwala na współpracę z siecią cieplną o parametrach $50 / 88^{\circ} \mathrm{C}$, przy wykorzystaniu jako dolnego źródła ciepła wody chłodzącej skraplacz turbiny, o średniej rocznej temperaturze $29^{\circ} \mathrm{C}$. Jako źródło energii do 
napędu pompy ciepła jest wymagana para nasycona o ciśnieniu $0,5 \mathrm{MPa}$, której dopuszczalna temperatura (z przyczyn technologicznych) nie może przekraczać $180^{\circ} \mathrm{C}$. Przyjęta do rozważań pompa ciepła charakteryzuje się wysoką wartością COP, równą 2.

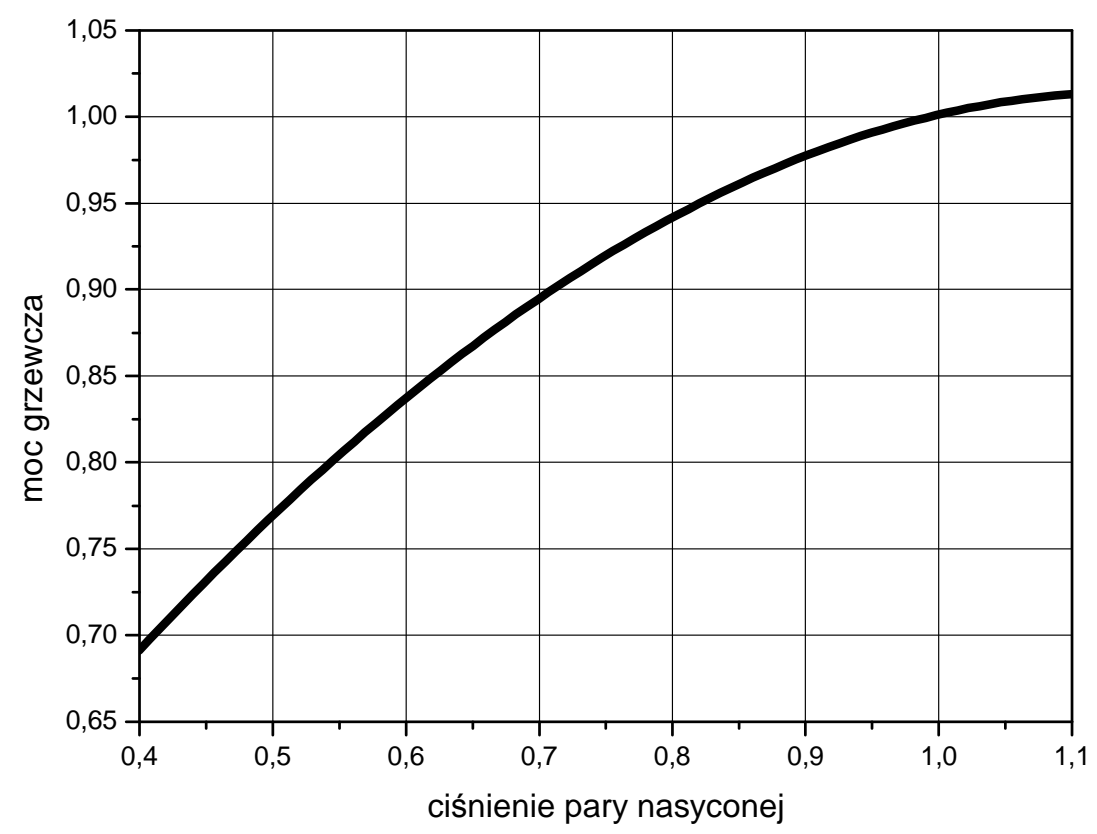

Rys. 3. Względna charakterystyka mocy cieplnej APC

Fig. 3. Relative characteristic of AHP thermal power

Integracja APC z blokiem parowym wymaga poboru pary z upustu turbiny, której ciśnienie jest najbliższe wymaganemu przez APC w warunkach nominalnych. W przypadku gdy pobierana z upustu para jest parą przegrzaną i posiada temperaturę wyższą od dopuszczalnej, konieczne jest jej wstępne przygotowanie przez wtrysk wody, np. ze zbiornika wody zasilającej w celu osiągnięcia stanu jej nasycenia. $\mathrm{W}$ analizowanym przypadku para pobierana $\mathrm{z} \mathrm{V}$ upustu o parametrach $0,58 \mathrm{MPa}$ i temperaturze $317^{\circ} \mathrm{C}$ jest parą przegrzaną. W tym przypadku zastosowano wtrysk wody z odgazowywacza o temperaturze $186^{\circ} \mathrm{C}$, co pozwoliło na przygotowanie pary mokrej na potrzeby APC o temperaturze $157,5^{\circ} \mathrm{C}$.

Praca pompy ciepła jest związana $\mathrm{z}$ wykorzystaniem niskotemperaturowego ciepła odpadowego, a zysk wynikający z zastosowania APC wiąże się ze zwiększeniem sprawności wytwarzania energii elektrycznej i ciepła w porównaniu z klasycznym przypadkiem uciepłownienia bloku parowego wymiennikiem ciepła zasilanym bezpośrednio parą $\mathrm{z}$ upustu. W przypadku zabudowy APC 
w układzie bloku parowego strumień pary niezbędny do uzyskania wymaganej mocy ciepłowniczej jest $\mathrm{w}$ analizowanym przypadku dwukrotnie niższy niż w klasycznym układzie z wymiennikiem ciepła, co prowadzi bezpośrednio do poprawy sprawności produkcji energii elektrycznej w tak skonfigurowanym układzie skojarzonym. W przypadku zastosowanej pompy ciepła o COP równym 2 urządzenie poza jednostką dostarczonej energii w postaci pary nasyconej dodatkowo odzyskuje jednostkę niskotemperaturowego ciepła odpadowego, które w innym przypadku byłoby skierowane przykładowo do chłodni kominowej. $\mathrm{W}$ ten sposób przy poborze jednostki ciepła z upustu turbiny są produkowane dwie jednostki ciepła na potrzeby grzewcze lub cele technologiczne. Wynika $\mathrm{z}$ tego, że moc pompy ciepła jest proporcjonalna do ilości energii pobranej $\mathrm{z}$ upustu turbiny i strumienia ciepła odzyskiwanego z wody chłodzącej opuszczającej skraplacz.

Przedstawiona propozycja integracji APC z układem bloku parowego pozwala na osiągnięcie wymiernych korzyści, które zależą głównie od mocy zabudowanej APC i ciepła przekazanego do celów grzewczych lub technologicznych. Zakładając moc pompy równą $100 \mathrm{MWt}$ i jej czas pracy z tą mocą w ciągu roku na poziomie 4380 godzin, można odzyskać 788,4 TJ ciepła odpadowego niskotemperaturowego. Tę ilość ciepła da się przeliczyć bezpośrednio na oszczędność paliwa. W przypadku opalania bloku parowego o mocy 900 MWe węglem kamiennym o wartości opałowej $23 \mathrm{MJ} / \mathrm{kg}$ lub węglem brunatnym o wartości opałowej 7,75 MJ/kg można się spodziewać oszczędności paliwa odpowiednio 36500 i $113000 \mathrm{Mg}$ rocznie. Oszczędności te można bezpośrednio przełożyć na zmniejszenie emisji $\mathrm{CO}_{2}$ do atmosfery o odpowiednio $79500 \mathrm{Mg}$ i $95000 \mathrm{Mg}$ rocznie.

Oprócz wspomnianych korzyści należy także uwzględnić wpływ uciepłownienia na moc maksymalną bloku. W przypadku zabudowy klasycznego wymiennika ciepła o mocy nominalnej $100 \mathrm{MWt}$ do jego zasilania jest wymagany strumień pary, który ogranicza możliwości produkcyjne bloku przy maksymalnej mocy ciepłowniczej do 875,2 MWe. Z kolei w przypadku zabudowy APC w układzie bloku parowego jest wymagany o połowę mniejszy strumień pary, co w mniejszym stopniu ogranicza możliwości produkcyjne energii elektrycznej i pozwala na produkcję z mocą ok. 887,6 MWe. W przypadku elektrowni zawodowych ze względu na ekonomię istotne są możliwości produkcji energii elektrycznej i każda ingerencja $w$ te możliwości może mieć wpływ na wynik finansowy. Jednak przy zabudowie w układzie bloku APC i produkcji ciepła na potrzeby grzewcze lub technologiczne możliwe staje się utrzymanie potencjału produkcyjnego energii elektrycznej. Wiąże się to z tym, że ilość pary pobieranej przez APC na potrzeby produkcji ciepła jest dwukrotnie niższa niż w przypadku klasycznego wymiennika ciepła. $\mathrm{Z}$ tego też względu nieznaczne zwiększenie strumienia pary świeżej produkowanej w kotle (w analizowanym przypadku o 1,4\% powyżej nominalnego) może rekompensować strumień pary pobieranej przez APC. W przypadku układu z wymiennikiem ciepła istniałaby konieczność 
dwukrotnego zwiększenia strumienia pary w porównaniu z układem z APC, co może być trudne ze względu na ograniczenia techniczne kotła i turbiny.

Istotnym parametrem przemawiającym za celowością zabudowy APC w układach bloków parowych w celu ich uciepłownienia jest sprawność tych układów. W przypadku analizowanego bloku parowego bez uciepłownienia sprawność wytwarzania energii elektrycznej brutto wynosi 49,04\%. W przypadku uciepłownienia bloku wymiennikiem ciepła o mocy 100 MWt sprawność ta spada do poziomu 47,69\%, wzrasta natomiast znacząco sprawność w skojarzeniu - do poziomu 53,14\%. Zabudowa APC o mocy $100 \mathrm{MWt}$ pozwala na osiągnięcie sprawności układu skojarzonego na poziomie jeszcze wyższym: 53,81\% przy sprawności elektrycznej na poziomie $48,36 \%$. Należy jednak podkreślić, że przedstawione wartości zależą od mocy uciepłownienia bloku, która w tym przypadku stanowi jedynie ok. $11 \%$ mocy elektrycznej.

Mając na uwadze proces odzysku ciepła z układu chłodzenia za pomocą APC, można ograniczyć obciążanie cieplne chłodni kominowej, co przekłada się bezpośrednio na straty wody. $\mathrm{Z}$ drugiej strony zastosowanie APC pozwala w pewnym stopniu na obniżenie temperatury wody zasilającej skraplacz, a tym samym obniżenie ciśnienia w skraplaczu, co wpływa także bezpośrednio na wzrost sprawności bloku parowego.

\section{Podsumowanie}

Przedstawiona propozycja zabudowy absorpcyjnej pompy ciepła w układzie bloku parowego pozwala na jego uciepłownienie przy minimalizacji negatywnych wpływów tego przedsięwzięcia. Jak wykazano, zabudowa APC pozwala na znaczące oszczędności paliwa oraz ograniczenie emisji $\mathrm{CO}_{2}$ do atmosfery. W przypadku oszczędności paliwa należy także pamiętać o innych korzyściach, takich jak: mniejsze zużycie sorbentu, mniejsza ilość popiołów, mniejsze straty wody w chłodni kominowej itp.

Oprócz wspomnianych aspektów należy się spodziewać korzyści finansowych z zabudowy APC, z możliwością większej produkcji energii elektrycznej niż w przypadku zabudowy klasycznego wymiennika ciepła.

\section{Podziękowanie}

Przedstawione $\mathrm{w}$ artykule wyniki zostały uzyskane w badaniach współfinansowanych przez Narodowe Centrum Badań i Rozwoju w ramach umowy SP/E/1/67484/10 - Strategiczny Program Badawczy - Zaawansowane technologie pozyskiwania energii: Opracowanie technologii dla wysokosprawnych ,zero-emisyjnych” bloków węglowych zintegrowanych z wychwytem $\mathrm{CO}_{2}$ ze spalin.

\section{Literatura}

[1] http://www.shuangliang.com/eng/product_show.asp?PID=42\&BigID=24. 
[2] Panowski M.: Modelowanie i optymalizacja skojarzonego obiegu siłowni parowej, rozprawa doktorska, Częstochowa 2006.

[3] Skibiński N.: Optymalizacja termoekonomiczna obiegu cieplnego siłowni energetycznej z wykorzystaniem algorytmów genetycznych, rozprawa doktorska, Częstochowa 2008.

\title{
THE CONCEPT OF IMPLEMENTATION OF ABSORPTION HEAT PUMP INTO THE STEAM POWER UNIT
}

\begin{abstract}
S u m m a r y
The paper presents concept of implementation of absorption heat pump into the supercritical steam power plant for additional heat production. Proposed concept was analysed based on numerical simulations that was realised with use of SimTech IPSEpro computer program. The integration of absorption heat pump and supercritical steam power unit was carried out. The results of analysis showed some advantages of such system. Furthermore, potential of fuel consumption savings that also causes significant reduction of carbon dioxide emission is found. Implementation of absorption heat pump allows to decrease negative impact of additional heat production on electricity generation in cogeneration system. The performed calculations allowed the assessment and comparison of basic coefficients such as gross electricity generation efficiency and efficiency of cogeneneration system for power unit with conventional heat exchanger and absorption heat pump.
\end{abstract}

Keywords: cogeneration, thermal cycle modelling, numerical simulations, absorption heat pump

DOI: $10.7862 / \mathrm{rm} .2015 .18$

Otrzymano/received: $14.09 .2014 r$

Zaakceptowano/accepted: $21.02 .2015 \mathrm{r}$. 